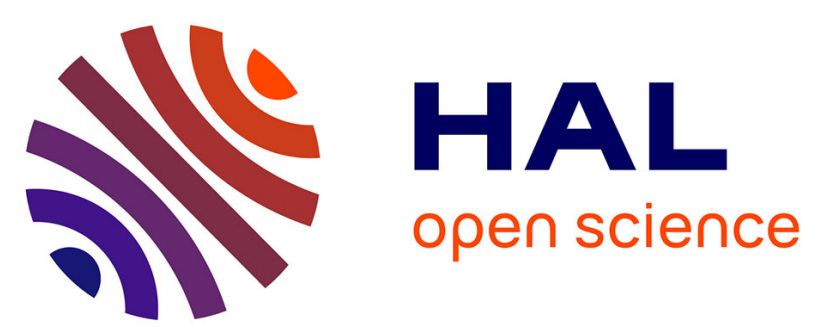

\title{
Who escort children: mum or dad? Exploring gender differences in escorting mobility among parisian dual-earner couples
}

\author{
Benjamin Motte-Baumvol, Olivier Bonin, Leslie Belton-Chevallier
}

\section{To cite this version:}

Benjamin Motte-Baumvol, Olivier Bonin, Leslie Belton-Chevallier. Who escort children: mum or dad? Exploring gender differences in escorting mobility among parisian dual-earner couples. Transportation, 2017, 44 (1), pp.139-157. 10.1007/s11116-015-9630-1 . hal-01170112

HAL Id: hal-01170112

https://hal.science/hal-01170112

Submitted on 18 Nov 2021

HAL is a multi-disciplinary open access archive for the deposit and dissemination of scientific research documents, whether they are published or not. The documents may come from teaching and research institutions in France or abroad, or from public or private research centers.
L'archive ouverte pluridisciplinaire HAL, est destinée au dépôt et à la diffusion de documents scientifiques de niveau recherche, publiés ou non, émanant des établissements d'enseignement et de recherche français ou étrangers, des laboratoires publics ou privés. 


\title{
WHO ESCORT CHILDREN: MUM OR DAD? EXPLORING GENDER DIFFERENCES IN ESCORTING MOBILITY AMONG PARISIAN DUAL-EARNER COUPLES
}

\author{
Benjamin Motte-Baumvol ${ }^{1}$
}

\section{THEMA (UMR 6049), Université de Bourgogne}

Associate Professor at the University of Burgundy, Benjamin Motte-Baumvol has a PhD in geography. His research is on daily mobility and accessibility in France and in Brazil.

\section{Olivier Bonin}

\section{LVMT, IFSTTAR, Université Paris-Est}

Olivier Bonin performs researches in statistics and in quantitative geography. Mostly with theoretical and modeling approaches, he works on urban morphogenesis, Transit-Oriented Development as well as on cartography and on epistemological issues in modeling applied to social sciences.

\section{Leslie Belton-Chevallier}

\section{DEST, IFSTTAR, Université Paris-Est}

Leslie Belton-Chevallier is sociologist of mobility. Her main research themes focus on different forms of mobility (daily, residential, real, virtual, within households, etc.) and their interactions.

1 Correspondence concerning this article should be addressed to Benjamin Motte-Baumvol, Laboratoire THEMA (UMR 6049), Université de Bourgogne, 2 boulevard Gabriel, 21000 Dijon, France; telephone: +33 380395731 ; fax: +33 3803939 10; e-mail: benjamin.motte@u-bourgogne.fr

This is a postprint version, the definitive version of this paper is :

Benjamin Motte-Baumvol, Olivier Bonin, Leslie Belton-Chevallier. Who escort children: mum or dad? Exploring gender differences in escorting mobility among parisian dual-earner couples. Transportation, Springer Verlag, 2017, 44 (1), pp.139-157. $\langle 10.1007 / \mathrm{s} 11116-015-9630-1\rangle$ 


\section{Summary}

The present article looks to pinpoint explanatory factors for the sharing of escorting of children in dual-earner families. It proposes a detailed analysis of inequalities and interactions in dualearner families when it comes to escorting children by taking into account the characteristics of trips to and from school for children, the characteristics of the parents' occupations, and the characteristics of the household. Compared with earlier research, the model considers more detailed data about the escorts' jobs, such as specific working hours, which provide a better understanding of the constraints on parents and insight into the choices made when both parents are in a position to escort their children. The findings depart somewhat from those of earlier work on the question because more specific data are considered. They show a marked gender inequality in escorting because mothers in dual-earner families do more than two-thirds of the escorting. But the factors explaining the sharing of escorting act almost symmetrically for both parents, with the effect of work starting and finishing times being preponderant. These models confirm that the inequality kicks in ahead of this: mothers in dual-earner households are more often than fathers in jobs with short working hours and which are more compatible with escorting.

\section{Keywords}

Escorting; Chauffeuring Trips; Dual-earner Families; Parenting; Household Interactions; Household Travel Survey 


\section{WHO ESCORT CHILDREN: MUM OR DAD? EXPLORING GENDER DIFFERENCES IN ESCORTING MOBILITY AMONG PARISIAN DUAL-EARNER COUPLES}

\section{Introduction}

Much research has been conducted in recent years into parents' escorting of children especially between home and school. This phenomenon lies at the junction of three areas of research into transport and mobility. The first of these areas relates to gender differences in mobility (Hanson and Pratt, 1995). It reveals that escorting is shared unequally between mothers and fathers (Gershuny, 1993). Even when both parents are earners, women do more of the chauffeuring (Schwanen, 2007) because they are considered to be the primary caregivers for the children (Rosenbloom and Burns, 1993). The second, more recent and very active area of research relates to factors prompting active modes of transport for children travelling to school and back. The challenge in this research, much of which has been published in medical journals, is the fight against overweight and obesity (McDonald, 2007; Saelens and Handy, 2008). The effects of the built environment have been investigated and the findings show that accessibility or proximity, mixed land use, density, aesthetics, pavements, street connectivity and safety are decisive factors in the choice about children's travel between active modes (walking, cycling) and, implicitly, being chauffeured by parents. But while these factors related to local planning are important, escorting remains primarily a question of the age of the children and the availability of parents, and especially mothers (McDonald, 2008). The third area of research that has been developing in recent years concerns interactions among members of the same household and their effects upon demand for transport (Bhat and Pendyala, 2005). Unlike the research in the other two fields, interaction models point to differences in factors prompting parents to take their children to school in the mornings or to bring them home in the afternoons (Vovsha and Petersen, 2005; Yarlagadda and Srinivasan, 2008). In these studies, whether the mother works and her working hours are both particularly decisive for morning trips. Schwanen et al. (2007) go further by constructing an interaction model combining several reasons for making trips. Apart from whether or not 
the parents work and their working hours, escorting may vary with the sharing of other activities between the parents, such as shopping.

The present article is part of this third area of research and looks to pinpoint explanatory factors for sharing the escorting of children in dual-earner families. It proposes a detailed analysis of inequalities and interactions in dual-earner families when it comes to escorting children by taking into account the characteristics of trips to and from school for children, the characteristics of the parents' occupations, and the characteristics of the household, much as in the models proposed by Vovsha and Petersen (2005) or Yarlagadda and Srinivasan (2008). Compared with earlier research, the model considers more detailed data about the escorts' jobs, such as specific working hours, which provide a better understanding of the constraints on parents and insight into the choices made when both parents are in a position to escort their children.

We posit three working hypotheses. The first is that escorting is shared unequally between men and women. All else being equal, it is more likely women will do the escorting. The second hypothesis is that interaction occurs between parents and that despite male/female inequality, the escorting of either partner depends on the occupational constraints of both partners and on the other's escorting. The third hypothesis postulates a spatial dimension to escorting. Schwanen (2007) reports that, for families living in the city centre, fathers escort their children more often than when families live on the outskirts.

The findings depart somewhat from those of earlier work on the question because more specific data are considered. They clearly show a marked gender inequality in escorting because mothers in dual-earner families do more than two-thirds of the escorting. But the factors explaining the sharing of escorting act almost symmetrically for both parents, with the effect of work starting and finishing times being preponderant. These models confirm that the inequality kicks in ahead of this: mothers in dual-earner households are more often than fathers in jobs with short working hours and which are more compatible with escorting, as described by England (1993). Conversely, 'split-shift' practices remain rare in dual-earner families in the 
Paris Region (lle-de-France), the dominant practice being for the same parent to accompany the children morning and evening.

\section{PREVIOUS RESULTS}

\subsection{Dual earners but not dual carers, women are the primary care-givers and chaperones}

Within couples, gender differences have been the subject of much research into the distribution and sharing of household activities, both domestic and parental. These activities are said to catalyse the continuation and re-production of considerable gender inequality (Pfefferkorn 2011). And yet, the growing participation of women in the labour market is indicative of a decline in the supposedly dominant model of the male breadwinner, where the man is the earner and the woman the homemaker and carer for the children (Crompton 1999; Lewis 2001). This model would seem to have given way to a new more equal ideal of sharing: the dual-earner/dual-carer model in which both men and women participate equally in household activities. However, in point of fact, the dominant model in western countries is rather that of dual-earner but not dual carer because many inequalities remain. Apart from differences in earnings, careers or access to employment, the distribution of jobs related to the home remains a stumbling block. In France the division of both domestic and parental labour has changed little (Ricroch 2012). Even within dual-earner families, the woman is often forced to take on a second service (Hochschild and Machung 1989) doing both her job and domestic chores. Women then find it increasingly difficult to reconcile work and private life (Garner et al. 2005). Although women do most of the escorting of children, men do contribute too. In the Netherlands, based on an ad hoc survey in Utrecht, Schwanen (2007) reports that men undertake $38.4 \%$ of school runs by dual-earner families. In the United States, men are less involved in escorting children according to the National Household Travel Survey (NHTS) making $30.5 \%$ of school trips whether the mother is in work or not (McDonald, 2008). On the 
basis of the Atlanta household activity-travel survey, Vovsha and Petersen (2005) report a similar level of participation by men in taking children school (29.8\%) and even lower participation in collecting them from school (23.3\%). Analysis of the Household Travel Survey (EGT) for lle-de-France set out below shows that men do $32 \%$ of the escorting.

The unequal contribution of parents to escorting children is not merely the reflection of occupational inequality (level of activity, job characteristics, etc.). While more women work part time and close to home, all else being equal, female household members do more escorting than males (Vovsha and Petersen, 2005). However, the findings by Vovsha and Petersen are based on analyses that partly take account of the characteristics of employment and of the working day of the parents. Yet the sector of activity, type of employment, and precise number of hours worked are all factors that affect the likelihood of escorting the children, as shown by Schwanen (2007). Ignoring the interaction with child commuting, Schwanen reports that, while women maintain a high level of escorting even when they have long working and commuting times, men seldom escort their children when the working and commuting time is above average. Short of a fair share-out of chores, fathers are more involved in escorting children when the mother works. Yarlagadda and Srinivasan (2008) report that men in dual-earner families are more likely to do some of the escorting.

\subsection{Interactions between partners}

Although the characteristics of each of the parents are decisive, some research underscores the crucial role of interactions among household members over escorting the children. But the emphasis falls primarily on the crossed effects between parents and children (McDonald, 2008; Vovsha and Petersen, 2005; Yarlagadda and Srinivasan, 2008) and not between the parents themselves. It is difficult to take account of interactions between parents insofar as the research primarily models children's travel to and from school and not escorting trips by either parent. In addition, two-parent and single-parent families are analysed indiscriminately. At 
best, the research confirms the fact that women do more chaperoning than men, all else being equal.

Schwanen (2007) proposes a closer analysis of the interactions between parents by considering dual-earner households and modelling the escorting of parents rather than children's commutes. The outcome is that women adapt their level of escorting to their partners' time constraints, and the partners offset to some small degree the woman's long working day by moderately increasing their participation in escorting. Moreover, Schwanen et al. (2007) paint a picture of partners who interact intensely but in different ways. They may share travelling by taking advantage of their complementarity (Ettema et al. 2007). For example, faced with very busy schedules, one partner may take care of the shopping while the other escorts the children. This specialisation in domestic activities would seem then to explain why it is predominantly women who do the escorting. However, by comparing the activity schedules of men and women and via analysis of their comments, some couples seem to have an escorting strategy. The father takes the children in the morning before going to work and the mother picks them up in the evening after work (Schwanen 2007). In this case, escorting is shared equally between the parents.

\subsection{Characteristics of children and of the area determining escorting}

Besides the characteristics of the parents and their interactions in terms of escorting, other factors related more directly to the children are reported to influence the parents' escorting. The motivations and the levels of escorting vary greatly with the age of the children. While children under the age of six are almost systematically accompanied to school, the proportion declines rapidly with increasing age (McDonald and Aalborg, 2009; Yarlagadda and Srinivasan, 2008). The number and age of siblings also affects the likelihood that parents will accompany them (Schwanen, 2007). Older siblings can accompany younger ones (Kwan, 1999) and parents are less concerned about safety when children go to school in groups (McDonald and Aalborg, 2009; McMillan, 2007). 
Insofar as children are seldom escorted by an active mode of transport but essentially by a motorised mode (McDonald, 2008) for reasons of convenience and compatibility with the parents' own commute (Faulkner et al., 2010; McMillan, 2007), the built environment of the home and school is reported to influence the likelihood of parents escorting their children. Several studies have shown that the choice between active and motorized modes is related to the built environment (Saelens and Handy, 2008), especially for children (McMillan, 2005). For many researchers, the aim is to show that public policies can act against problems of overweight and obesity in the population and notably in children by encouraging them to use active modes of transport. Among the characteristics of the built environment, the main factors investigated include accessibility or proximity, mixed land use, density, aesthetics, pavements, street connectivity and safety. Although these factors are not to be considered in isolation but must be associated with other factors such as transport options available to parents and children, social/cultural norms, and socio-demographic characteristics, they have some effect on the mode of transport of children and indirectly on the probability of them being accompanied. All told, these factors mean that the locations of the home and children's school or parents' work and their characteristics affect the escorting of children.

\section{HYPOTHESES AND RESEARCH DESIGN}

With regard to the bibliographic framework set out and the factors highlighted, we shall examine the inequalities between parents of dual-earner households in escorting their children on the basis of data from the Household Travel Survey (HTS) of the Paris Region. The survey was not designed specifically for this research but it does contain a fairly precise description of mobility for escorting and for commuting. It was conducted by face-to-face interviews at the respondents' homes and captures information on all trips undertaken by household members aged six and over on a designated survey day as well as socio-demographic information (for complete details of survey design see DREIF (2004)). In all, 10.478 households were surveyed between October 2001 and April 2002. Of those households, about 1.400 were dual-earner 
families with at least one child. The work analysed escorting (or its absence) by parents of these households. Given the relatively moderate sample size, we capture here only dualearner couples of different sexes.

We posit three working hypotheses. The first is that escorting is shared unequally between men and women, all else being equal. For a working day of equal length, with the same starting and finishing times, it is more likely women will do the escorting. The second hypothesis is that interaction occurs between parents and that despite male/female inequality, the escorting of one partner depends on their own occupational constraints and those of their partner and on the partner's escorting. Thus the probability that the father will escort the children home in the afternoon will be greater if the mother works late and takes the children to school in the morning. The third hypothesis postulates a spatial dimension to escorting. Schwanen (2007) reports that, for families living in the city centre, fathers escort their children more often than when families live on the outskirts, especially for the morning trips. This work confirms this.

To answer these questions and test the three hypotheses, we perform multivariate analysis based on HTS data for the Paris Region. The results set out here are based on multinomial logit models. The first two predict the likelihood of escorting in the morning, the afternoon or both, one for men and one for women. The next two look exclusively at households which escort their children. They predict the likelihood of it being the father or the mother who does the escorting, one for the morning and one for the afternoon. We try to capture differences in explanatory factors and different strategies in father/mother and morning/afternoon escorting.

\subsection{Child escorting in the HTS}

The trips studied in this research are the escorting of children by their parents. Parents must live as couples and have jobs. The Paris Region HTS indicates whether the person escorted is part of the household and if so whether it is a child of the couple. In this way, we can circumvent the restriction of the survey-which does not enquire into the mobility of children 
under six years old-by inferring it from the parents' escorting mobility. This study therefore covers the escorting of all children and not just those aged over six, as in recent research on children's travel. Moreover, all trips were taken into account and not just school runs. It is assumed here that interactions between parents over escorting are not confined to school and that escorting should be taken into account comprehensively so as to better analyse it.

Even so, school remains the main reason and probably the one that structures escorting by parents. Vovsha and Petersen (2005) show that if taking the child involves a detour on the way to work this will have a negative effect on the likelihood that parents will escort the child. For this reason, it is necessary to identify more specifically trips relating to school so as to deduce its location, especially for children under six years old. The HTS from the Paris Region indicates the reasons for the trip made by the person escorted. Yet, only $70 \%$ of children under six were escorted to school. To offset this, the detour for parents for other children in the family was applied to children under six for which the detour could not be determined. For children over six who were not escorted to school, information about the location of the school was obtained from analysing the mobility of the children themselves. The school location was included in the models notably by calculating a level of effort, that is, the detour in terms of time involved in escorting to or from school on the commute to and from work.

\subsection{Characteristics of the partners' working days}

Information on the mother and fathers' work status, occupation, education, transport mode and distance to work is recorded in the HTS for the Paris Region. These characteristics are known for all of the dual-earner households surveyed. It is also possible to infer the number of hours worked by each parent from the departure and arrival times for commutes, which is a variable used in many models about escorting or children's school journeys. But we also used the starting and finishing times at work to determine whether they were compatible with their children's school times and to check whether parents are in a position to take their children to and from school. In the French school system, which is very largely state-run, school times up 
to the age of 10 are fixed, starting at about 8.30 am (depending on the local area and schools) and ending at around $4.30 \mathrm{pm}$. Moreover, in most schools, there are after-school arrangements for children to remain up to $6.00 \mathrm{pm}$. This time extension means parents can more easily collect their children from school. Two variables indicating the compatibility of parents' working hours with morning and afternoon school times were used in the models presented. Above the age of 10 , school starting and finishing times may be more variable. However, up to the age of 15 at least, the school day from 8.30 am to $4.30 \mathrm{pm}$ remains the dominant model.

\subsection{Interactions between partners examined in two models with instrumental variables}

In order to introduce interactions into log models between escorting trips, a problem of endogeneity has to be overcome. If one tries to explain the likelihood that one of the parents escorts the children in the morning by the fact that they do or do not escort the children in the afternoon, it is obvious that the cause and effect may work in both directions. A parent who collects the children in the afternoon will be less likely to take them in the morning; but a parent who takes them in the morning will also be less likely to collect them in the afternoon.

We therefore construct four models with instrumental variables to predict the likelihood of escorting in the morning and the afternoon for each of the parents. These are standard logistic regression models. The instruments used are a set of socio-demographic variables similar to those presented below in the final models. These probabilities of escorting the children are then used as explanatory variables in the models to capture any interaction between escorting trips.

\section{RESULTS}

\subsection{Escorting for dual-earner families in the Paris Region}

Among the dual-earner households studied, $55 \%$ of parents escorted their children at least once on the survey day. This figure ranges from more than $70 \%$ for households with at least 
one child under the age of six to $31 \%$ when the household has at least one grown-up child. Escorting is usually done by women since almost half of mothers escort their children versus less than one-third of fathers (Table 1). Far more mothers than fathers escort both mornings and afternoons, and a few more mothers than fathers escort just in the mornings, which is consistent with observations in other countries. A relative balance is found between fathers and mothers for escorting in the afternoons alone. However, it can be observed at this point that some characteristics of women's employment may be related to these gender differences. More women begin work after 8.30 am, giving them the opportunity to escort their children in that time slot.

TABLE 1. - Descriptive variables of dual-earner households with one or more children

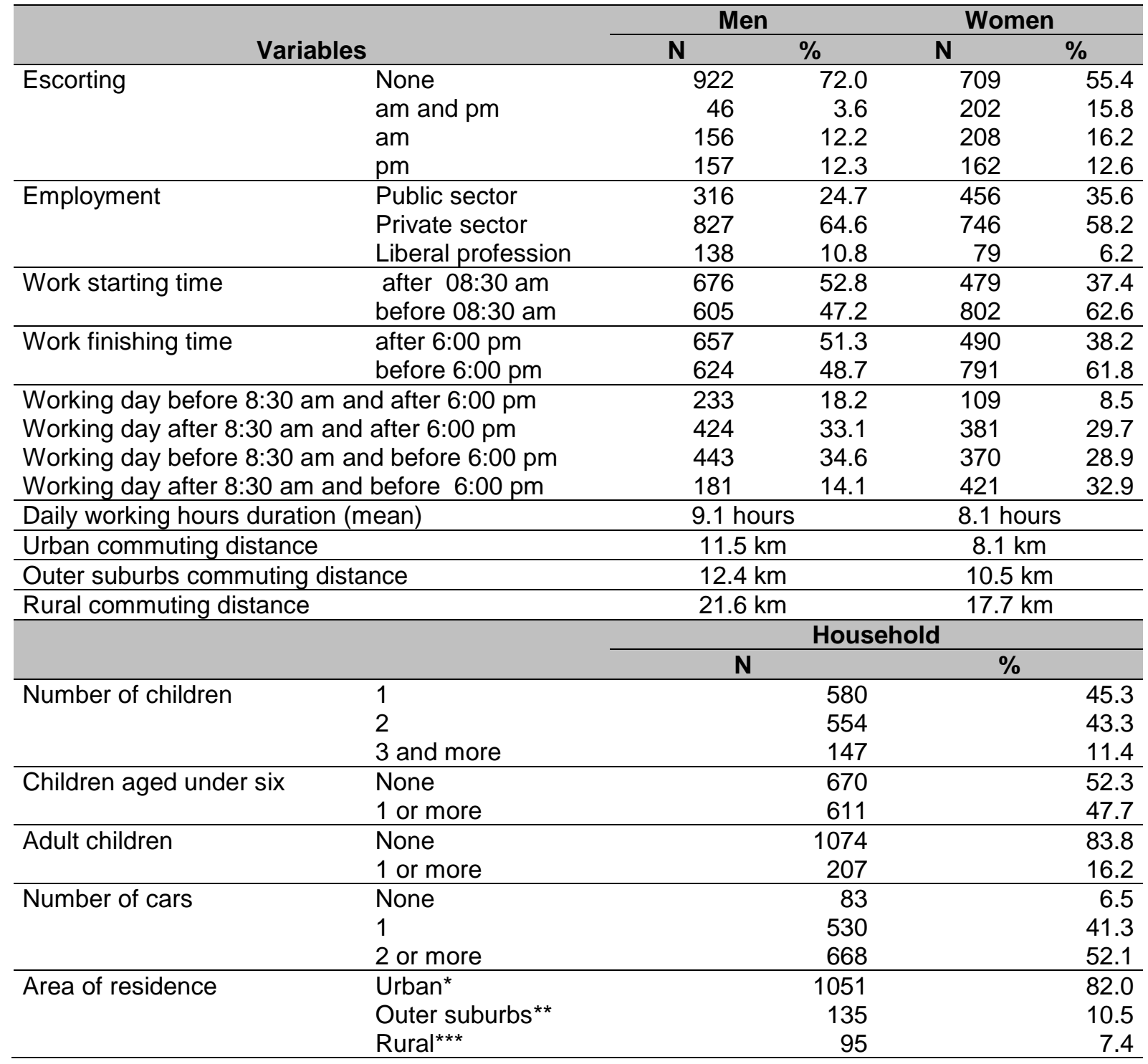


* Localities in the Paris agglomeration

** Little urbanised localities on the outskirts but within the Paris agglomeration

*** Rural localities in the study area because within the administrative boundaries of the lle de France region

We introduce variables into the models to describe the ability to take charge of escorting duties, such as the nature of employment, work time, possession of cars and commuting characteristics, as well as variables describing the need for escorting, such as the number of children or the area of residence. While colinearity probably exists between these variables, it does not impact the models: the variance inflation factor is very close to 1 for all models.

We have already indicated that introducing interactions between escorting duties in the morning and in the afternoon for both partners leads to an equation system that must be estimated with the help of instrumental variables (double least squares) to overcome the problem of endogeneity. We are aware that endogeneity may also be present for other variables, especially for work starting and finishing times: the need to escort children may lead parents to choose a job with appropriate working times. As in all logistic models, we are only able to reveal correlation and not causality. However, in the framework of the Paris Region, we recall that a large number of households do not escort children, so we can assume that parents are more likely to change their decision to escort (with the help of nannies to escort children) than to change jobs. Besides, we were unable to select omitted variables in the HTS, i.e. variables correlated with work times and determinants of escorting duties.

TABLE 2. - LOGISTIC MODEL: Probability the father escorts both mornings and afternoons, mornings only or afternoons only

\begin{tabular}{llrrrrl}
\hline & & Estimate & $\begin{array}{c}\text { Std. } \\
\text { Error }\end{array}$ & t-value & $\operatorname{Pr}(>|\mathbf{t}|)$ \\
\hline am and pm & & $-5.7 \mathrm{E}+00$ & $1.3 \mathrm{E}+00$ & -4.525 & $6 \mathrm{E}-06^{* * *}$ \\
$\mathrm{am}$ & & $-5.8 \mathrm{E}+00$ & $9.7 \mathrm{E}-01$ & -5.831 & $5 \mathrm{E}-09^{* * *}$ \\
$\mathrm{pm}$ & $-3.7 \mathrm{E}+00$ & $7.3 \mathrm{E}-01$ & -5.039 & $5 \mathrm{E}-07 \quad * * *$ \\
\hline $\mathrm{am}$ and pm & Mother escorts am & $-4.4 \mathrm{E}-01$ & $3.0 \mathrm{E}-01$ & -1.445 & 0.148 \\
$\mathrm{am}$ & Mother escorts am & $-5.6 \mathrm{E}-01$ & $1.8 \mathrm{E}-01$ & -2.930 & $0.003^{* *}$ \\
$\mathrm{pm}$ & Mother escorts am & $5.1 \mathrm{E}-01$ & $2.0 \mathrm{E}-01$ & 2.530 & $0.011^{*}$ \\
\hline $\mathrm{am}$ and pm & Mother escorts pm & $-3.2 \mathrm{E}-01$ & $2.1 \mathrm{E}-01$ & -1.522 & 0.128 \\
$\mathrm{am}$ & Mother escorts pm & $1.6 \mathrm{E}-01$ & $1.3 \mathrm{E}-01$ & 1.264 & 0.206 \\
$\mathrm{pm}$ & Mother escorts pm & $-4.5 \mathrm{E}-01$ & $1.2 \mathrm{E}-01$ & -3.562 & 0.000 \\
am and pm & Private sector employment & $-1.8 \mathrm{E}-01$ & $3.5 \mathrm{E}-01$ & -0.530 & 0.596 \\
$\mathrm{am}$ & Private sector employment & $6.6 \mathrm{E}-02$ & $2.3 \mathrm{E}-01$ & 0.284 & 0.776
\end{tabular}




\begin{tabular}{|c|c|c|c|c|c|c|}
\hline pm & Private sector employment & $-5.9 \mathrm{E}-01$ & 2.1E-01 & -2.850 & 0.004 & ** \\
\hline $\mathrm{am}$ and $\mathrm{pm}$ & Liberal profession & $-1.5 \mathrm{E}+00$ & $8.1 \mathrm{E}-01$ & -1.857 & 0.063 & \\
\hline am & Liberal profession & $-3 E-01$ & 3.6E-01 & -0.838 & 0.401 & \\
\hline pm & Liberal profession & $-1.3 \mathrm{E}+00$ & $4.5 \mathrm{E}-01$ & -2.921 & 0.003 & ** \\
\hline $\mathrm{am}$ and $\mathrm{pm}$ & Start work after 8:30 am & $10 \mathrm{E}-01$ & $3.4 \mathrm{E}-01$ & 2.960 & 0.003 & ** \\
\hline am & Start work after 8:30 am & $1.7 \mathrm{E}+00$ & 2.3E-01 & 7.177 & $7 \mathrm{E}-13$ & *** \\
\hline $\mathrm{pm}$ & Start work after $8: 30 \mathrm{am}$ & $-1.5 \mathrm{E}-01$ & $2.2 \mathrm{E}-01$ & -0.701 & 0.483 & \\
\hline $\mathrm{am}$ and $\mathrm{pm}$ & Finish work before 6:00 pm & $1.2 \mathrm{E}+00$ & $3.6 \mathrm{E}-01$ & 3.381 & 0.001 & $* * *$ \\
\hline am & Finish work before $6: 00 \mathrm{pm}$ & $-7.2 \mathrm{E}-01$ & $2.2 \mathrm{E}-01$ & -3.213 & 0.001 & ** \\
\hline pm & Finish work before $6: 00 \mathrm{pm}$ & $1.9 \mathrm{E}+00$ & 2.6E-01 & 7.730 & $1 \mathrm{E}-14$ & *** \\
\hline $\mathrm{am}$ and $\mathrm{pm}$ & Commute distance $(\mathrm{m})$ & $-5.0 \mathrm{E}-05$ & $1.8 \mathrm{E}-05$ & -2.677 & 0.007 & ** \\
\hline am & Commute distance (m) & $-4.9 \mathrm{E}-06$ & 8.7E-06 & -0.567 & 0.570 & \\
\hline pm & Commute distance (m) & $-1.2 \mathrm{E}-05$ & $8.5 \mathrm{E}-06$ & -1.365 & 0.172 & \\
\hline $\mathrm{am}$ and $\mathrm{pm}$ & 2 children & $3.8 \mathrm{E}-01$ & $3.7 \mathrm{E}-01$ & 1.029 & 0.303 & \\
\hline am & 2 children & $6.1 \mathrm{E}-01$ & 2.3E-01 & 2.571 & 0.010 & * \\
\hline $\mathrm{pm}$ & 2 children & $-1.9 \mathrm{E}-01$ & 2.3E-01 & -0.829 & 0.407 & \\
\hline $\mathrm{am}$ and $\mathrm{pm}$ & 3 or more children & $4.5 \mathrm{E}-02$ & $5.1 \mathrm{E}-01$ & 0.087 & 0.930 & \\
\hline am & 3 or more children & 7.4E-01 & $2.9 \mathrm{E}-01$ & 2.595 & 0.009 & ** \\
\hline pm & 3 or more children & 7.3E-03 & $3.2 \mathrm{E}-01$ & 0.023 & 0.981 & \\
\hline $\mathrm{am}$ and $\mathrm{pm}$ & 1 or more children under 6 & $9.8 \mathrm{E}-01$ & $4.4 \mathrm{E}-01$ & 2.228 & 0.026 & * \\
\hline am & 1 or more children under 6 & $8.6 \mathrm{E}-01$ & $2.6 \mathrm{E}-01$ & 3.302 & 0.001 & *** \\
\hline pm & 1 or more children under 6 & 9.3E-01 & $2.8 \mathrm{E}-01$ & 3.393 & 0.001 & *** \\
\hline am and $\mathrm{pm}$ & 1 or more adult children & $-2.0 \mathrm{E}+00$ & $8.1 \mathrm{E}-01$ & -2.448 & 0.013 & * \\
\hline am & 1 or more adult children & $-5.9 \mathrm{E}-01$ & 4.1E-01 & -1.449 & 0.147 & \\
\hline $\mathrm{pm}$ & 1 or more adult children & $-4.4 \mathrm{E}-01$ & $4.4 \mathrm{E}-01$ & -0.989 & 0.323 & \\
\hline $\mathrm{am}$ and $\mathrm{pm}$ & 1 car & $9.9 \mathrm{E}-01$ & $9.5 \mathrm{E}-01$ & 1.053 & 0.292 & \\
\hline $\mathrm{am}$ & $1 \mathrm{car}$ & $1.9 \mathrm{E}+00$ & $8.2 \mathrm{E}-01$ & 2.317 & 0.020 & * \\
\hline $\mathrm{pm}$ & $1 \mathrm{car}$ & $6.8 \mathrm{E}-01$ & $5.1 \mathrm{E}-01$ & 1.346 & 0.178 & \\
\hline am and $p m$ & 2 or more cars & $9.5 \mathrm{E}-01$ & $9.7 \mathrm{E}-01$ & 0.979 & 0.328 & \\
\hline am & 2 or more cars & $2.3 \mathrm{E}+00$ & 8.3E-01 & 2.779 & 0.005 & ** \\
\hline pm & 2 or more cars & $8.4 \mathrm{E}-01$ & $5.2 \mathrm{E}-01$ & 1.615 & 0.106 & \\
\hline $\mathrm{am}$ and $\mathrm{pm}$ & Home in outer suburbs & $9.9 \mathrm{E}-01$ & $4.3 \mathrm{E}-01$ & 2.310 & 0.021 & * \\
\hline am & Home in outer suburbs & $6.6 \mathrm{E}-02$ & $3.2 \mathrm{E}-01$ & 0.208 & 0.835 & \\
\hline $\mathrm{pm}$ & Home in outer suburbs & $1.9 \mathrm{E}-01$ & $2.9 \mathrm{E}-01$ & 0.654 & 0.513 & \\
\hline $\mathrm{am}$ and $\mathrm{pm}$ & Home in rural area & $1.1 \mathrm{E}+00$ & $5.5 \mathrm{E}-01$ & 2.030 & 0.042 & * \\
\hline am & Home in rural area & $-1.3 \mathrm{E}-01$ & 3.7E-01 & -0.342 & 0.732 & \\
\hline $\mathrm{pm}$ & Home in rural area & $4.5 \mathrm{E}-01$ & 3.4E-01 & 1.314 & 0.189 & \\
\hline
\end{tabular}

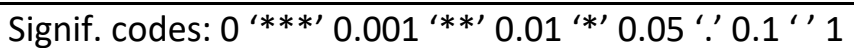

Source: Calculated by the authors from the Paris HTS2001-2002

TABLE 3. - LOGISTIC MODEL: Probability the mother escorts both mornings and afternoons, mornings only or afternoons only

\begin{tabular}{|c|c|c|c|c|c|c|}
\hline & & Estimate & Std. Error & t-value & $\operatorname{Pr}(>|t|)$ & \\
\hline am and $p m$ & & $-5.2 \mathrm{E}+00$ & 8.6E-01 & -6.053 & $1 \mathrm{E}-09$ & *** \\
\hline am & & $-3.7 \mathrm{E}+00$ & 8.5E-01 & -4.359 & $1 \mathrm{E}-05$ & *** \\
\hline $\mathrm{pm}$ & & $-3.2 \mathrm{E}+00$ & $9.2 \mathrm{E}-01$ & -3.480 & 0.000 & *** \\
\hline am and pm & Father escorts am & $-2.2 \mathrm{E}-01$ & $1.1 \mathrm{E}-01$ & -2.002 & 0.045 & * \\
\hline am & Father escorts am & $-2.9 \mathrm{E}-01$ & $1.1 \mathrm{E}-01$ & -2.653 & 0.008 & ** \\
\hline $\mathrm{pm}$ & Father escorts am & $2.7 \mathrm{E}-01$ & $1.2 \mathrm{E}-01$ & 2.363 & 0.018 & * \\
\hline am and pm & Father escorts pm & $-2.9 \mathrm{E}-01$ & $1.0 \mathrm{E}-01$ & -2.915 & 0.003 & ** \\
\hline am & Father escorts pm & 2.1E-01 & $9.9 \mathrm{E}-02$ & 2.086 & 0.037 & * \\
\hline $\mathrm{pm}$ & Father escorts pm & $-3.7 \mathrm{E}-01$ & $1.1 \mathrm{E}-01$ & -3.506 & 0.000 & *** \\
\hline am and $\mathrm{pm}$ & Private sector employment & $-1.5 \mathrm{E}-01$ & $1.9 \mathrm{E}-01$ & -0.789 & 0.430 & \\
\hline am & Private sector employment & 4.3E-01 & 2.0E-01 & 2.153 & 0.031 & * \\
\hline pm & Private sector employment & $-2.5 \mathrm{E}-01$ & 2.0E-01 & -1.250 & 0.211 & \\
\hline $\mathrm{am} \mathrm{a}$ & Liberal profession & $-1.0 \mathrm{E}+00$ & $4.7 \mathrm{E}-01$ & -2.215 & 0.027 & \\
\hline am & Liberal profession & 1.0E-01 & 3.8E-01 & 0.274 & 0.784 & \\
\hline
\end{tabular}




\begin{tabular}{|c|c|c|c|c|c|c|}
\hline $\mathrm{pm}$ & Liberal profession & $8.2 \mathrm{E}-02$ & $3.9 \mathrm{E}-01$ & 0.208 & 0.835 & \\
\hline $\mathrm{am}$ and $\mathrm{pm}$ & Start work after 8:30 am & 8.3E-01 & $1.9 \mathrm{E}-01$ & 4.240 & $2 \mathrm{E}-05$ & 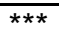 \\
\hline am & Start work after 8:30 am & $1.2 \mathrm{E}+00$ & $2.2 \mathrm{E}-01$ & 5.757 & 9E-09 & *** \\
\hline pm & Start work after 8:30 am & $-4.8 \mathrm{E}-01$ & $1.9 \mathrm{E}-01$ & -2.488 & 0.013 & * \\
\hline $\mathrm{am}$ and $\mathrm{pm}$ & Finish work before 6:00 pm & $1.3 \mathrm{E}+00$ & $2.1 \mathrm{E}-01$ & 6.439 & $1 \mathrm{E}-10$ & $\overline{* \star \star}$ \\
\hline am & Finish work before $6: 00 \mathrm{pm}$ & $-1.6 \mathrm{E}-01$ & $1.8 \mathrm{E}-01$ & -0.897 & 0.369 & \\
\hline $\mathrm{pm}$ & Finish work before $6: 00 \mathrm{pm}$ & $1.7 \mathrm{E}+00$ & 2.6E-01 & 6.545 & $6 \mathrm{E}-11$ & *** \\
\hline $\mathrm{am}$ and $\mathrm{pm}$ & Commute distance $(\mathrm{m})$ & $-4.6 \mathrm{E}-05$ & $1.2 \mathrm{E}-05$ & -3.946 & $8 \mathrm{E}-05$ & *** \\
\hline am & Commute distance (m) & $-3.4 \mathrm{E}-05$ & $1.1 \mathrm{E}-05$ & -3.139 & 0.002 & ** \\
\hline $\mathrm{pm}$ & Commute distance (m) & $4.5 \mathrm{E}-06$ & $9.7 \mathrm{E}-06$ & 0.470 & 0.638 & \\
\hline $\mathrm{am}$ and $\mathrm{pm}$ & 2 children & $4.9 \mathrm{E}-01$ & $1.9 \mathrm{E}-01$ & 2.642 & 0.009 & ** \\
\hline am & 2 children & 3.9E-01 & $1.8 \mathrm{E}-01$ & 2.152 & 0.031 & * \\
\hline pm & 2 children & $-6.5 \mathrm{E}-02$ & 2.1E-01 & -0.314 & 0.753 & \\
\hline am and $p m$ & 3 or more children & $1.8 \mathrm{E}-01$ & $3.1 \mathrm{E}-01$ & 0.581 & 0.560 & \\
\hline am & 3 or more children & $-2.2 \mathrm{E}-02$ & 3.1E-01 & -0.071 & 0.943 & \\
\hline pm & 3 or more children & 2.6E-01 & $2.9 \mathrm{E}-01$ & 0.903 & 0.367 & \\
\hline am and $\mathrm{pm}$ & 1 or more children under 6 & $1.5 \mathrm{E}+00$ & $2.2 \mathrm{E}-01$ & 6.646 & $3 \mathrm{E}-11$ & *** \\
\hline am & 1 or more children under 6 & 7.2E-01 & $2.2 \mathrm{E}-01$ & 3.272 & 0.001 & ** \\
\hline $\mathrm{pm}$ & 1 or more children under 6 & $1.0 \mathrm{E}+00$ & 2.3E-01 & 4.494 & 7E-06 & *** \\
\hline am and $\mathrm{pm}$ & 1 or more adult children & $-1.7 \mathrm{E}+00$ & $4.0 \mathrm{E}-01$ & -4.255 & $2 \mathrm{E}-05$ & *** \\
\hline am & 1 or more adult children & $-1.2 \mathrm{E}+00$ & $3.2 \mathrm{E}-01$ & -3.714 & 0.000 & *** \\
\hline $\mathrm{pm}$ & 1 or more adult children & $-2.9 \mathrm{E}-01$ & $3.2 \mathrm{E}-01$ & -0.904 & 0.366 & \\
\hline $\mathrm{am}$ and $\mathrm{pm}$ & $1 \mathrm{car}$ & 7.7E-01 & $5.3 \mathrm{E}-01$ & 1.468 & 0.142 & \\
\hline am & 1 car & $8.9 \mathrm{E}-01$ & $5.1 \mathrm{E}-01$ & 1.757 & 0.078 & \\
\hline pm & $1 \mathrm{car}$ & $6.6 \mathrm{E}-02$ & $6.1 \mathrm{E}-01$ & 0.108 & 0.913 & \\
\hline am and $\mathrm{pm}$ & 2 or more cars & $1.4 \mathrm{E}+00$ & $5.3 \mathrm{E}-01$ & 2.625 & 0.009 & ** \\
\hline am & 2 or more cars & $1.3 \mathrm{E}+00$ & $5.2 \mathrm{E}-01$ & 2.554 & 0.010 & * \\
\hline $\mathrm{pm}$ & 2 or more cars & 2.1E-01 & $6.2 \mathrm{E}-01$ & 0.334 & 0.738 & \\
\hline $\mathrm{am}$ and $\mathrm{pm}$ & Home in outer suburbs & $2.4 \mathrm{E}-01$ & $3.0 \mathrm{E}-01$ & 0.806 & 0.420 & \\
\hline am & Home in outer suburbs & $5.5 \mathrm{E}-03$ & $2.8 \mathrm{E}-01$ & 0.018 & 0.984 & \\
\hline $\mathrm{pm}$ & Home in outer suburbs & 1.7E-01 & 3.0E-01 & 0.574 & 0.566 & \\
\hline am and $\mathrm{pm}$ & Home in rural area & $9.4 \mathrm{E}-01$ & $3.1 \mathrm{E}-01$ & 3.070 & 0.002 & ** \\
\hline am & Home in rural area & $-7.7 \mathrm{E}-02$ & 3.6E-01 & -0.213 & 0.831 & \\
\hline pm & Home in rural area & 2.3E-01 & $3.4 \mathrm{E}-01$ & 0.687 & 0.492 & \\
\hline
\end{tabular}

The first model (Table 2) predicts the likelihood that fathers will escort the children in the mornings or in the afternoons, or that they will escort them mornings and afternoons. The second model (Table 3) predicts the same probabilities for mothers. The main explanatory variables of the two models work in similar ways: the start and finish times of work for the parents and the presence of children under the age of six in the household. The presence of young children has a very positive effect on the probability of escorting in the mornings and/or afternoons for fathers and mothers. For working hours, a late start increases the probability of escorting in the mornings only or mornings and afternoons. Conversely, an early finish increases the likelihood of children being escorted in the afternoons only or mornings and afternoons. Apart from the main explanatory variables, two other variables have significant 
effects on the probability of parents escorting children. The likelihood of escorting in the mornings increases for parents in households with several children and for those with one or more cars. The likelihood of escorting mornings and afternoons is also greater for mothers in households with two children and/or two or more cars.

Concerning the three hypotheses posited in this article, the factors of gender differences seem somewhat reduced in these first two models. The first relates to the type of occupation, the second to the presence of a third adult in the household. Thus men who are private sector employees or in the professions are less likely to escort children in the afternoons than are men who are public sector employees. For women in similar occupations, there is no significant reduction in the likelihood of them escorting their children according to type of occupation except for escorting them in the mornings for private sector workers and for double escorts (mornings and afternoons) for those in the professions. Conversely, the presence of an adult child significantly reduces the likelihood the mother will escort the children in the mornings or mornings and afternoons. For the partner, the presence of a third adult reduces only the probability of both morning and afternoon escorts and barely significantly. For afternoon escorts, the presence of a third adult has no significant effect, even for mothers. It can be postulated that afternoon escorts are those which weigh somewhat less heavily on mothers (cf. Table 3), even if they still perform them more often than fathers. The second hypothesis relates to forms of interaction between parents. In the first series of models, there are two types of interaction. First, if one parent escorts the children in the mornings or afternoons, the likelihood that the other parent escorts the children in the same time slot is very low. Just one parent seems to escort in a given time slot. Secondly, if one parent escorts in the mornings, it is much more likely that the other parent will escort the children in the afternoons. Parents are complementary between mornings and afternoons. The final hypothesis relates to the existence of a spatial dimension of escorting. Such an effect is not very frequent in models. Only living in a rural area significantly increases the likelihood of escorting both mornings and afternoons. The same is true for the outer suburbs, but for fathers only. This result, based on 
a small sample, is presumably because parents are more likely to escort children when they live in the outer suburbs and in low density areas where schools (nursery, pre-school, primary) are often furthest from home. Less directly, the models below tend to show that the commuting distance (in metres) reduces the propensity to escort both mornings and afternoons for fathers and for mothers, and to escort children in the mornings for mothers. Thus the distance between home and work might have a negative overall effect on the likelihood of escorting children in dual-earner households in the outer suburbs and rural areas, given that these distances generally increase as one moves away from the city centre (Table 2)

\subsection{In which cases do fathers do more escorting than mothers?}

For parents who escort their children in the mornings only, in more than two-thirds of instances it is the mother who does this (Table 4). Yet in nearly half of households (49.1\%), fathers have working hours that are compatible with taking children to school in the mornings. In our sample, more women use public transport which is less amenable to escorting (Prédali 2005), especially in the mornings.

TABLE 4. - Descriptive variables of household escorting in the mornings

\begin{tabular}{llrr}
\hline \multicolumn{1}{c}{ Variables } & & N & \% \\
\hline Escorting & Mother & 372 & 69.5 \\
& Father & 164 & 30.5 \\
\hline Start work after 8:30 am & None & 85 & 15.8 \\
& Mother & 188 & 35.0 \\
& Father & 77 & 14.3 \\
& Both & 187 & 34.8 \\
\hline Father's transport mode & Public transport & 137 & 25.6 \\
& Car & 345 & 64.4 \\
& Foot & 53 & 9.9 \\
\hline Mother's transport mode & Public transport & 192 & 35.9 \\
& Car & 301 & 56.2 \\
& Foot & 42 & 7.9 \\
\hline Adult child & None & 498 & 92.9 \\
& 1 or more & 38 & 7.1 \\
\hline Home area & Urban & 437 & 81.4 \\
& Outer suburbs & 55 & 10.3 \\
& Rural & 44 & 8.3 \\
\hline
\end{tabular}

Source: Calculated by the authors from the Paris HTS 2001-2002 
The model below (Table 5) predicts the probability of fathers escorting more than mothers in the mornings. The main explanatory variable relates to the work starting times. Unsurprisingly, the likelihood that fathers will do the escorting is greater when their working hours are compatible with those of the school and when the mothers' working hours are incompatible. Conversely, the probability fathers will escort children is far lower when their work starting times are not compatible with school times and mothers' working hours are. Where both parents' working hours are compatible, no trend stands out. Intuitively, in such a situation, it would be expected that mothers would do more of the escorting. For all the other variables in the model, symmetry of effects between fathers and mothers can be observed. For example, having just one car increases the likelihood that the parent using that means of transport for going to work will also escort the children. Similarly, making a big detour on the journey to work to drop off the children (materialised here by the level of effort to deviate from the route) reduces the likelihood of escorting for fathers and mothers alike. There is therefore no amplification of the asymmetry between men and women with respect to the factors that prompt them to escort the children, at least for those parents who do escort their children. That women do most of the escorting in the mornings seems therefore to be related to a structure effect: more women than men apparently have working hours that are compatible with escorting, somewhat more limited access to car use, and jobs closer to home. Lastly, we do not highlight in this model interaction between morning and afternoon escorting for households escorting in the mornings.

TABLE 5. - LOGISTIC MODEL: Probability that the father rather than the mother will escort the children in the mornings (only households escorting in the mornings)

\begin{tabular}{llrrrr}
\hline & Estimate & Std.Error & t-value & $\operatorname{Pr}(>|\mathrm{t}|)$ \\
\hline Father escorts & & $-9.5 \mathrm{E}-01$ & $4.4 \mathrm{E}-01$ & -2.148 & $0.032^{*}$ \\
\hline Father escorts & Start work mother after 8:30 am & $-2.1 \mathrm{E}+00$ & $4.1 \mathrm{E}-01$ & -5.162 & $2 \mathrm{E}-07^{* * *}$ \\
Father escorts & Start work father after 8:30 am & $1.5 \mathrm{E}+00$ & $3.7 \mathrm{E}-01$ & 4.122 & $4 \mathrm{E}-05^{* * *}$ \\
Father escorts & Start work both after 8:30 am & $2.8 \mathrm{E}-01$ & $3.1 \mathrm{E}-01$ & 0.864 & 0.387 \\
\hline Father escorts & Car father & $6.3 \mathrm{E}-01$ & $3.0 \mathrm{E}-01$ & 2.116 & $0.034^{*}$ \\
Father escorts & Foot father & $-4.2 \mathrm{E}-03$ & $4.7 \mathrm{E}-01$ & -0.009 & $0.993^{*}$ \\
\hline Father escorts & Car mother & $-5.8 \mathrm{E}-01$ & $2.7 \mathrm{E}-01$ & -2.093 & $0.036^{*}$ \\
Father escorts & Foot mother & $-3.5 \mathrm{E}-01$ & $4.9 \mathrm{E}-01$ & -0.698 & 0.485 \\
\hline Father escorts & 1 or more adult children & $6.6 \mathrm{E}-01$ & $4.1 \mathrm{E}-01$ & 1.618 & $0.106^{* *}$ \\
\hline Father escorts & Commute distance father $(\mathrm{m})$ & $-3.9 \mathrm{E}-05$ & $1.2 \mathrm{E}-05$ & -3.385 & $0.001^{* * *}$ \\
\hline Father escorts & Commute distance mother $(\mathrm{m})$ & $6.3 \mathrm{E}-05$ & $1.5 \mathrm{E}-05$ & 4.064 & $5 \mathrm{E}-05^{* * *}$ \\
\hline
\end{tabular}




\begin{tabular}{llrrrr}
\hline Father escorts & Level of effort father & $-2.5 \mathrm{E}-04$ & $8.5 \mathrm{E}-05$ & -2.978 & $0.003^{* *}$ \\
\hline Father escorts & Level of effort mother & $3.2 \mathrm{E}-04$ & $8.5 \mathrm{E}-05$ & 3.758 & $0.000^{* * *}$ \\
\hline Father escorts & Home in outer suburbs & $-2.1 \mathrm{E}-01$ & $3.6 \mathrm{E}-01$ & -0.582 & 0.561 \\
Father escorts & Home in rural area & $-4.5 \mathrm{E}-01$ & $4.4 \mathrm{E}-01$ & -1.003 & 0.316 \\
\hline \multicolumn{5}{c}{ Signif. codes: $0^{* * * \prime} 0.001^{* * * \prime} 0.01^{* \prime \prime} 0.05^{\prime \prime} 0.1^{\prime \prime} 1$} \\
& Source: Calculated by the authors from the Paris HTS2001-2002 &
\end{tabular}

Escorting in the evenings is in the great majority of instances done by women too, in a ratio of 1 to 2 (Table 6). Later work finishing times for men are conducive to more escorting for women than for men in the afternoons. The model predicting the likelihood of escorting in the afternoons for men compared with women shows, as for the morning model, a degree of symmetry of effects between men and women (Table 7). However, work finishing times aside, there is less symmetry for afternoon than for morning escorting. Thus, the length of the commute of one parent significantly increases the likelihood that the other will escort more in the afternoons, but less so than in the mornings. Moreover, the symmetry observed in the mornings in terms of car use or level of effort disappears. In the evenings, the likelihood the father will escort more than the mother depends above all on the fact that the mother travels by car or has a sizeable level of effort.

To conclude, in these two models, the spatial dimension does not seem to be directly involved since the household residential area has little or no effect on escorting by one parent rather than the other.

TABLE 6. - Descriptive variables of households escorting in the afternoons

\begin{tabular}{llrr}
\multicolumn{1}{c}{ Variables } & N & \multicolumn{2}{c}{$\%$} \\
\hline Escorting & Mother & 330 & 66.2 \\
& Father & 169 & 33.8 \\
\hline Finish work before 6: 00 pm & Neither & 64 & 12.9 \\
& Mother only & 182 & 36.6 \\
& Father only & 92 & 18.5 \\
& Both & 160 & 32.0 \\
\hline Father's transport mode & Public transport & 140 & 28.0 \\
& Car & 313 & 62.6 \\
& Foot & 47 & 9.4 \\
\hline Mother's transport mode & Transports publics & 185 & 37.1 \\
& Car & 278 & 55.7 \\
& Foot & 36 & 7.2 \\
\hline Adult child & None & 458 & 91.8 \\
& 1 or more & 41 & 8.2 \\
\hline Home area & Urban & 399 & 79.9 \\
& Outer suburbs & 55 & 10.9
\end{tabular}


Rural

TABLE 7. - LOGISTIC MODEL: Probability that the father escorts in the afternoons rather than the mother (only for households escorting in the afternoons)

\begin{tabular}{|c|c|c|c|c|c|c|}
\hline & & Estimate & Std.Error & t-value & $\underset{P r}{\operatorname{Pr}}>|\mathrm{t}|$ & \\
\hline Father escorts & & $-3.5 \mathrm{E}-01$ & $4.53 \mathrm{E}-01$ & -3.771 & 0.437 & \\
\hline Father escorts & Finish work mother before 6:00 pm & $-2.3 E+00$ & $4.31 \mathrm{E}-01$ & -5.427 & $6 \mathrm{E}-08$ & $* * *$ \\
\hline Father escorts & Finish work father before 6:00 pm & $2.1 \mathrm{E}+00$ & 3.89E-01 & 5.492 & $4 \mathrm{E}-08$ & $* * *$ \\
\hline Father escorts & Finish work both before $6: 00 \mathrm{pm}$ & 1.1E-01 & $3.29 \mathrm{E}-01$ & 0.341 & 0.732 & \\
\hline Father escorts & Car father & $4.6 \mathrm{E}-03$ & $2.97 \mathrm{E}-01$ & 0.015 & 0.987 & \\
\hline Father escorts & Foot father & $-2.9 \mathrm{E}-01$ & 4.89E-01 & -0.599 & 0.549 & \\
\hline Father escorts & Car mother & $-6.0 \mathrm{E}-01$ & $2.94 \mathrm{E}-01$ & -2.041 & 0.041 & * \\
\hline Father escorts & Foot mother & $-5.2 \mathrm{E}-01$ & $5.64 \mathrm{E}-01$ & -0.924 & 0.355 & \\
\hline Father escorts & 1 or more adult children & $5.0 \mathrm{E}-01$ & $4.29 \mathrm{E}-01$ & 1.155 & 0.248 & \\
\hline Father escorts & Commute distance father $(\mathrm{m})$ & $-2.9 \mathrm{E}-05$ & $1.23 E-05$ & -2.401 & 0.016 & * \\
\hline Father escorts & Commute distance mother $(\mathrm{m})$ & 3.4E-05 & $1.54 \mathrm{E}-05$ & 2.217 & 0.027 & * \\
\hline Father escorts & Level of effort father & $-6.5 \mathrm{E}-05$ & $4.62 \mathrm{E}-05$ & -1.415 & 0.157 & \\
\hline Father escorts & Level of effort mother & $1.5 \mathrm{E}-04$ & $6.17 \mathrm{E}-05$ & 2.504 & 0.012 & * \\
\hline Father escorts & Home in outer suburbs & $6.7 \mathrm{E}-01$ & $3.72 \mathrm{E}-01$ & 1.792 & 0.073 & \\
\hline Father escorts & Home in rural area & $-1.6 \mathrm{E}-01$ & 4.49E-01 & -0.349 & 0,727 & \\
\hline
\end{tabular}

\section{Discussion}

In dual-earner families in lle-de-France, half escort their children, and those with young children escort them more than those whose children are adults. Unsurprisingly, women escort twice as much as men, conducting two-thirds of the escorts. Above all, gender inequalities are marked by the proportion of women accompanying both mornings and afternoons. They are four times as many and represent $35 \%$ of women who escort their children.

Observation of gender differences and significant variables in models reveals that the most significant variables are nonetheless common to men and women. They produce the same type of effect on the likelihood of escorting, especially in the mornings and to a lesser degree in the afternoons. These variables are, by order of importance, the presence of young children in the household, then work starting and finishing times, and their compatibility with the childcare or school times. Differences between men and women are few and have little effect in the respective models predicting the probability of escorting. However, men escort less in the afternoons when they are private sector employees or in the professions whereas women who 
are employed in the private sector escort more in the mornings. Next, men are more likely to escort in the mornings the more children they have, while this effect is weak or non-existent for women. Lastly, and conversely, the presence of a grown-up child in the household greatly reduces the probability women will escort in the mornings or afternoons. However, for men, these effects are weak (mornings and afternoons) and generally non-existent. Moreover, women appear more sensitive to the length of their commutes for escorting in the mornings and for morning and afternoon escorting.

This first series of results highlights the slight gender differences as to the determinants of escorting for dual-earner households that can be captured with this type of model. The explanations for the very marked inequality between men and women in escorting are therefore to be sought ahead of the escorting decisions. The models reveal that the parents' employment conditions are the main determinants of the decision to escort. Now, as has been seen, there are inequalities with respect to the parents' working days. The mother's working day is often more compatible with escorting than the father's, especially in terms of starting and finishing times, commuting distance, type of employment and means of transport. She then does most of the escorting. Unfortunately, the HTS does not enable us to determine whether the mother's choice of a job which is compatible with escorting is dictated by the need to ensure such escorting or whether there are other determinants.

The second series of models pertaining to escorting dual-earner households confirms the observation about unequal escorting between parents prompted by the difference between their working days rather than by greater investment by mothers, regardless of the constraints of their working day and of the fathers' working day. The second series of models shows symmetry between parents of the effects of factors affecting the probability of escorting. It will be observed that this symmetry is stronger overall in the mornings than the afternoons, which might be in part because there is more escorting in the mornings than in the afternoons.

Thus for dual-earner households, gender inequalities in their escorting are not to be sought in the relations between these practices and the parents' working days. Ahead of this, the 
inequality lies in the choice of employment and the working day it involves. Many results show that women in dual-earner households tend to have jobs with shorter and more flexible working hours, jobs that are closer to home and that allow them to do most of the care-giving and escorting for the children (England, 1993).

The link for escorting between the partners and/or between afternoon and morning revealed by Schwanen (2007) in the Netherlands is also apparent in the case of Paris. It is above all apparent as a negative link between the probability of one partner making escorting trips and the other partner doing so too, particularly in the morning. It is also apparent as a negative link between the probability of one partner conducting escorting trips both in the morning and afternoon. These effects express what has been said above and what emerged from the descriptive analysis: the dominant model is that of a household where a single partner is responsible for escorting either in the morning or in the evening. The strongest and most systematic effect involves a link between the partners for escorting trips during a given half day, which we shall characterise as optimisation by the sharing of escorting trips between the couple before and after work. This sharing, which we shall characterise as complementarity, occurs when one partner takes on escorting duties before work and the other does so after work. The probability of complementarity between the partners with regard to escorting is low. Next, the third form of interaction in escorting involves the performance of escorting duties in the morning and evening by the same partner.

A final element is the spatial dimension of escorting. Parents in dual-earner households escort their children when they live in the outer suburbs of cities, in low-density areas. Schools there are less commonly within walking distance but there are also no safe and pleasant paths for pedestrians. Yet the spatial effect identified remains slight and is applicable only in certain cases. It tends to increase the likelihood that one of the parents will escort the children in the mornings or afternoons. Children are escorted more systematically in such areas. This effect is more striking because longer average commuting distances in these areas tend to reduce the likelihood of parents escorting their children. The spatial dimension of escorting therefore 
arises less directly, through commuting distances or levels of effort which appear to be greater in less densely populated areas. These variables act more significantly on the relative likelihood of escorting by one or other of the parents. However, being persuaded of the importance of geography in gender-based mobility (Uteng and Cresswell 2008), further exploration should be done by examining the data of mobility surveys of other regions or cities in France.

\section{CONCLUSION}

In short, exploitation of the HTS for lle-de-France reveals that the practice of escorting children differs between men and women within dual-earner households, with mothers being more active than fathers. Nonetheless, in dual-earner households, interactions are often at work in the sharing of escorting since the escorting by one parent affects the practices of the other parent. To return to the research by Schwanen et al. (2007), interactions between fathers and mothers most probably result in complementarity (if one escorts at one time, the other will have significantly less chance of escorting at the same time) or specialisation (just one parent takes charge of all escorting) in the management of these trips. More generally, looking at variables related to escorting by one or other parent and especially those relating to the other parent (work times, commuting distance, etc.), these links operate in similar ways on the escorting of children and the way it is shared. All else being equal, differences in escorting between mothers and fathers would seem to be minimal.

But it is known that in terms of gender and the sharing of activities within the household, all else is far from equal. If there is parity between the partners in terms of activity or of residential location, many inequalities remain in terms of employment conditions (working hours, location, etc.) and modes of transport, etc. These differences necessarily affect the population structure and ultimately the escorting that depends on it. The results presented are therefore the outcome of a structure effect related both to the conditions in which our sub-sample was selected and to the inherent and persistent differences in gender and the sharing of daily 
activities and trips. A better understanding of the inequalities in terms of escorting would require a better understanding of the gender-based distribution of all of the household's travel patterns.

Inequalities in terms of domestic activities and more especially of care-giving for children are largely determined by the socio-spatial or cultural characteristics of the populations under study (Craig and Mullan 2011). Contextualisation of the results is crucial to the proper analysis of them. It averts the many controversies and misunderstandings in gender studies, as recalled by Hanson (2010). Our findings are for the Paris Region and cannot be generalised to other French cities where the characteristics of dual-earner families (skills, age, family size or working hours) and spatial context (public transport, car ownership, detached housing) are different. Yet the extension of this work to other French cities, or even to the whole of France on the basis of the French National Household Travel Survey, would bring out what is specifically Parisian and/or French in our findings. However, the present results already exhibit similarities with earlier results for other countries and cities, notably those reported by Schwanen et al. (2007), Kwan (1999) and Vovsha and Petersen (2005).

\section{References}

Bhat, C., Pendyala, R. (2005) Modeling intra-household interactions and group decisionmaking. Transportation 32, 443-448.

Crompton, R. (1999) The decline of the male breadwinner: explanations and interpretations. Restructuring gender relations and employment: The decline of the male breadwinner. ed Crompton, R. Oxford University Press, Oxford, UK, pp. 1-25.

Direction Régionale de l'Equipement d'lle-de-France (2004) Les déplacements des franciliens en 2001-2002. Enquête Globale de Transport. Paris, France.

England, K.V.L. (1993) Suburban pink collar ghettos: The spatial entrapment of women? Annals of the Association of American Geographers 83, 225-242. 
Ettema, D., Schwanen, T., Timmermans, H. (2007) The effect of location, mobility and sociodemographic factors on task and time allocation of households. Transportation 34, 89-105.

Faulkner, G.E.J., Richichi, V., Buliung, R.N., Fusco, C., Moola, F. (2010) What's "quickest and easiest"?: parental decision making about school trip mode. International Journal of Behavioral Nutrition and Physical Activity 7, 1-11.

Garner, H., Méda, D., Senik, C. (2005) Conciliation: The lessons of household studies. Travail et emploi 102, 57-67.

Gershuny, J. (1993) Escorting children: impact on parental lifestyle. Children, transport and the quality of life. ed Hillman, M. Policy Studies Institute, London, pp. 62-76.

Hanson, S. (2010). Gender and mobility: new approaches for informing sustainability. Gender, Place and Culture 17(1), 5-23.

Hanson, S., Pratt, G. (1995) Gender, work, and space. Routledge, New York, NY.

Hochschild, A.R., Machung, A. (1989) The second shift: Working parents and the revolution at home. Viking Pinguin, New York, NY.

Kwan, M.P. (1999) Gender, the home-work link, and space-time patterns of nonemployment activities. Economic Geography 75, 370-394

Lewis, J. (2001) The decline of the male breadwinner model: implications for work and care. Social Politics 8, 152-169.

McDonald, N.C. (2007) Active transportation to school: trends among US schoolchildren, 1969-2001. American journal of preventive medicine 32, 509-516.

McDonald, N.C. (2008) Household interactions and children's school travel: the effect of parental work patterns on walking and biking to school. Journal of Transport Geography 16, 324-331.

McDonald, N.C., Aalborg, A.E. (2009) Why parents drive children to school: implications for Safe Routes to School programs. Journal of the American Planning Association 75, 331-342. 
McMillan, T.E. (2005) Urban form and a child's trip to school: the current literature and a framework for future research. Journal of Planning Literature 19, 440-456.

McMillan, T.E. (2007) The relative influence of urban form on a child's travel mode to school. Transportation Research Part A: Policy and Practice 41, 69-79.

Prédali, F. (2005) Mother mobility in the Paris area. Networks and Communication Studies 19, 211-228.

Rosenbloom, S., Burns, E. (1993) Gender differences in commuter travel in Tucson: implications for travel demand management programs. Transportation Research Record 1404, 82-90.

Saelens, B.E., Handy, S.L. (2008) Built environment correlates of walking: a review. Medicine and science in sports and exercise 40, 550-566.

Schwanen, T. (2007) Gender Differences in Chauffeuring Children among Dual-Earner Families. The Professional Geographer 59, 447-462.

Schwanen, T., Ettema, D., Timmermans, H. (2007) If you pick up the children, I'll do the groceries: spatial differences in between-partner interactions in out-of-home household activities. Environment and Planning A 39, 2754-2773.

Vovsha, P., Petersen, E. (2005) Escorting children to school: statistical analysis and applied modeling approach. Transportation Research Record: Journal of the Transportation Research Board 1921, 131-140.

Yarlagadda, A.K., Srinivasan, S. (2008) Modeling children's school travel mode and parental escort decisions. Transportation 35, 201-218. 